\title{
Do Melipona bicolor (Apidae, Meliponinae) workers distinguish relatedness among different physogastric queens?
}

\author{
Wladimir J. Alonso*, Tarcila Lucena, Carla M. Fracasso, \\ Hayo H.W. Velthuis, Vera Lucia Imperatriz-Fonseca
}

\author{
Departamento de Ecologia, Instituto de Biociências, Universidade de São Paulo, \\ Rua do Matão, Travessa 14, no. 321 CEP: 05508-900, Cidade Universitária, São Paulo, Brazil
}

(Received 2 January 1998; accepted 8 July 1998)

\begin{abstract}
The prediction that the polygynous stingless bee Melipona bicolor workers should distinguish physogastric queens to whom they have different degrees of relatedness was tested. One colony with two physogastric queens was monitored for 5 consecutive days for the occurrence of the provision and oviposition processes (POP) of individually marked workers. We recorded cell provisioning, egg laying, and cell sealing. The presence of one or both of the queens during each POP was recorded. After that, one of the queens from the colony used in the first experiment was removed from the colony and substituted by two other non-related physogastric queens, from other colonies. In both cases preferences by workers towards their mother or aunt or to the unrelated queens were not detected. In a third experiment we demonstrated that guard bees at entrance of a colony do not reject a physogastric foreign queen. Evolutionary and husbandry implications are discussed. (C) Inra/DIB/AGIB/Elsevier, Paris
\end{abstract}

kin recognition / polygyny / provision and oviposition processes / Melipona bicolor

\section{INTRODUCTION}

After Hamilton's publications [10] it is now widely accepted that an individual increases its overall fitness by helping to rear the offspring of a relative. It is expected that this help should be preferentially directed toward individuals that share a great degree of relatedness with the actor. In euso- cial insects, nestmates with different degrees of relatedness are often found; this is due to polyandry, to polygyny and the meeting of different generations (sisters, nieces, etc.) in the same colony.

In honeybees, polyandry brings about important varieties of intra-colonial relatedness. In experiments where some evidence

\footnotetext{
* Correspondence and reprints

E-mail: wja@altavista.net
} 
of worker discrimination based on degrees of relatedness was found the results have been questioned because: $A$ ) the preference for full sisters may be an artefact of the use of heritable phenotypic markers to distinguish sub-families; B) task specialisation (such as repeated observations on the same bee) among lineages was not controlled; C) faulty statistical analyses and no blind observations were used; and/or D) the genetic diversity of the colony was artificially low because queens were experimentally inseminated with the sperm of only two or three males, although they usually mate with seven to 17 males $[1,4,6,15,24,25,34$, $35]$. We can add that, even so, the discrimination found could be merely a by-product of nestmate recognition $[5,6,8,9,31]$

To add empirical data to this discussion taking into account these criticisms, we performed experiments that did not involve artificial lineages, used marked bees (if discrimination occurs), and chose a stingless bee species that has a naturally low level of relatedness variability. Furthermore, the criticism that the discrimination could be a byproduct or a kind of nestmate recognition can be partially overcome. This, if we deal with situations of discrimination that hardly could be directed to individuals of other colonies instead of nestmates (e.g. brood care), but involve individuals with different degrees of relatedness into the colony.

Melipona bicolor Lepeletier is a facultatively polygynous species $[2,16,30]$ which is abundant in the Brazilian Atlantic Rain forest $[26,36]$. Since queens are taught to mate only once $[17-19,30]$, the polygynous condition allows us to assess the interactions among individuals with different levels of relatedness. The highly eusocial condition (as defined by Michener [22]) provides us with a repertoire of behaviours that seem unlikely to be confounded with those behaviours that can be directed towards individuals of other colonies. In fact, stingless bees have massive provisioning, and queens often eat worker-laid eggs, which are an important component of their diet $[29,32]$, and are dependent on the cell provisioning by the workers. These actions happen in the provisioning and oviposition process (POP) in a highly stereotyped fashion $[28,29,38]$.

In the present study we tested the tendency of workers to behave differently towards physogastric queens to which they have different degrees of relatedness, one of them being their mother, the other being possibly an aunt (exp. 1) or being a foreign queen (exp. 2). Additionally it was tested whether the system of foreign queen recognition could occur at the entrance of the colony (exp. 3). Evolutionary and husbandry implications are discussed.

\section{METHODS}

\subsection{Experiment 1}

For this experiment, a polygynous colony originating from Cunha (São Paulo State, Brazil) was chosen and maintained in the Bee Laboratory of the Ecology Department of the São Paulo University. It was kept in an observation hive (modified from [27]) at a constant temperature $\left(27-29^{\circ} \mathrm{C}\right)$. Bees were allowed to forage outside, but sometimes the colony was also provided syrup (sugar with water 1:1) and dehydrated pollen. Observations were made using red light. This colony had two physogastric queens (Q1, Q2) who were seen in the colony for the first time in October 1996 - and who were probably sisters. The queens were marked with coloured dots of paint on their thorax.

For 1 month before the beginning of the behavioural observations, we removed the lower combs (which are, for this species, the older ones) and placed them in a hive extension $(15 \times 10 \times 6 \mathrm{~cm})$ connected to the main nest by a short tube $(6 \mathrm{~cm})$. In this hive extension, nurse bees could enter and help new bees to emerge. These young bees, which could be identified by their pale integument, were collected daily (also 505during the days of behavioural observations), provided individually with numbered paper tags pasted onto the thorax and returned to the colony. For 5 consecutive days and nights (15-20 January 1997) all POPs were monitored, and the individuals that had taken part in the following categories (or states) were recorded. 
Workers: cell provisioning prior to oviposition; egg laying prior and after queen oviposition; cell sealing after queen oviposition.

Queens: presence in front of the cell during the POP process; egg laying.

The behaviours performed by the workers were scored in relation to the queen(s) present, but cell closure behaviour was scored in relation to the queen that oviposited. In order to assess a possible preference toward one queen or the other, the total number of behaviours performed by each worker to each queen was recorded. A score of one was attributed when the behaviour was performed to only one queen. In cases where both queens were present in the POP the score was divided in two halves, one half for each queen. Only those workers that had been observed participating in four or more POPs were chosen for analysis. Repetitions of the cell provisioning behaviour by the same worker in the same POP were not considered. We assumed that each one of these behavioural categories has the same 'altruistic value', and therefore are equally computed.

The possibility that workers stimulated by the presence of one queen were not inhibited by the presence of the second was also considered. Therefore, in a second analysis, only those POPs in which only one queen was present (and again with workers that had been observed participating in four or more POPs) were considered, and again it was tested whether the workers had any preference.

To test worker preference towards any queen we used the log-likelihood ratio statistics ( $\mathrm{G}$ test), which may be used instead of chi-square when $n$ is not large [37]. In order to test the null hypothesis (no preference of workers toward any queen), each worker was supposed to perform behaviours to each queen in a ratio similar to the ratio of the number of the POPs in which each queen was present.

\subsection{Experiment 2}

From the beginning of June 1997, we again marked the emerged bees, for a period of over 1 month. Both queens (Q1 and Q2) were taken from the colony just before starting POP monitoring. Queen Q3 from a different colony which, together with Q2 (control treatment), was introduced as a substitute for one of the queens (Q1). Q3 was immediately accepted, but had a low participation in the POPs. Therefore, after 1 day of observations, another queen Q4, was also introduced, which quickly began to participate. For this reason the first day of our recording is not considered for the present data analysis. The introduced queens Q3 and Q4 are neither daughters nor sisters of Q2. All the other methods for the monitoring session ( 31 June-5 July) and data analysis are as described for experiment 1.

\subsection{Experiment 3}

Between 21 July and 25 July, eight physogastric queens were removed from their colony, transported in a tube (length $3 \mathrm{~cm}$, diameter $1.3 \mathrm{~cm}$ ), and immediately placed at the entrance of another randomly chosen queenright colony. In order to enter the colony, the queens had to pass workers along a transparent tube of $40-50 \mathrm{~cm}$ in length and 1.3 in diameter that connected the brood nest with the exterior. The tube is long enough to allow the guards and foraging bees (the most aggressive ones) to meet and reject an intruder. Furthermore, this artificial tube is considered by the workers as being an internal part of the nest. This is indicated by the fact that the guards bees always stay defending its exterior extremity (which is closed by the bees with mud with the exception of a small hole which allows the passage of one bee at a time).

A successful introduction was considered when, at least $3 \mathrm{~h}$ after the introduction, the foreign queen was observed on the comb, being in apparent good condition and without experiencing any aggression from the workers. After this period each queen was reintroduced into the colony of origin.

\section{RESULTS}

\subsection{Experiment 1}

A total of 84 POP sequences were recorded during the 5 days of the experiment. Of these, 20 with Q1, 37 with Q2 and 31 with both queens present in the POP (the sum is not 88 because some of the POPs had changes regarding the queen present). A total of 154 marked workers were recorded participating in the POPs. Of these, 104 workers participated in at least four POPs and thus could be used for studying the degree to which preference for a particular queen occurs (figure I). 
If the colony were to consist of two separate groups of workers, each group supporting mainly their own mother queen, then this figure should have shown a distinct separation of the workers. This is not the case. Instead, there is a gradual change from workers having a high ratio of performing behaviour in favour of queen 1 into a high ratio in favour of queen 2 . This gradual change reflects random differences rather than a distinct choice by individual bees $($ Log likelihood ratio G-test $=42.2, \mathrm{df}=52$, $p=0.83$ ).

If we restrict the analysis to those POPs in which only one queen was present, the result is the same (figure 2). Again preference toward anyone of the queens was not detected (log-likelihood ratio G-test $=41.5$, $\mathrm{df}=39, P=0.36$ ).

\subsection{Experiment 2}

A total of 79 POP sequences were recorded during the 4 days of the experiment. Of these, 24 with Q1, 25 with Q3 or $\mathrm{Q} 4$, and 43 with two or three queens present in the POP (the sum is not 79 because some of the POPs had changes regarding the queen present). A total of 131 marked workers were recorded participating in the POPs. Of these, 74 participated in at least

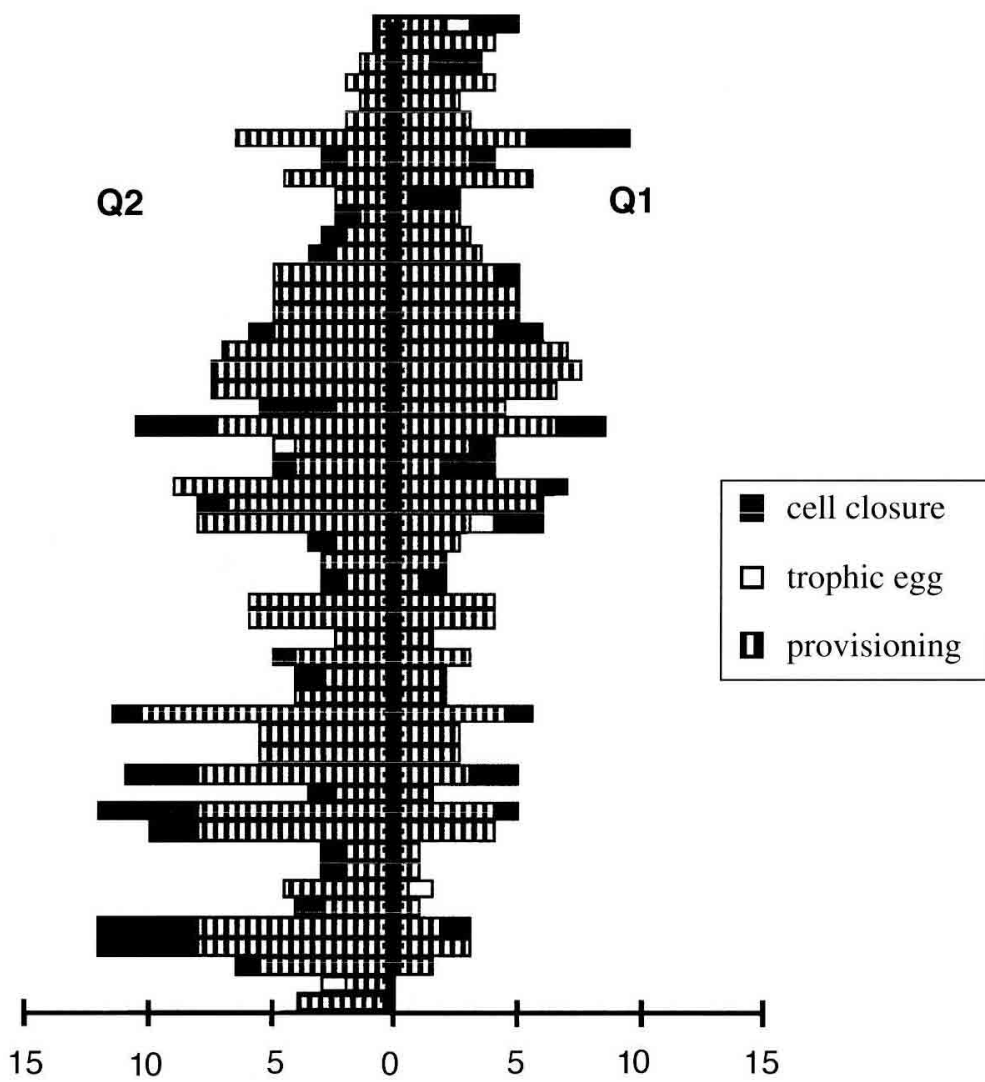

Figure 1. Behaviours performed by each worker (individual workers are represented by each horizontal bar) to each of the sister queens (left and right side of the vertical axis: Q2 and Q1, respectively). Workers are arranged vertically in a rank derived from the ratio of behaviour performed to $Q 2$ over Q1, so that the workers directing their behaviours mostly toward Q1 are represented in the top and those workers directing their behaviours toward Q2 are in the bottom. 
four POPs and thus could be used for the analysis of preference (figure 3 ).

Again, the distribution of the POP activities of these bees does not show a populational segregation. Instead, it agrees well with a random distribution of participation in the POPs, irrespective of whether the familiar or the foreign queen oviposited (loglikelihood ratio G-test $=21.8, \mathrm{df}=36$, $P=0.97)$. If we restrict the analysis to those POPs where only one queen was present (figure 4), we arrive at the same conclusion $(\log$-likelihood ratio G-test $=24.0, \mathrm{df}=26$, $P=0.57$ ).

\subsection{Experiment 3}

All the queens introduced at the entrance of the colony were accepted in the colony. Each introduced queen was surrounded by several workers in the tube making a kind of court, but the workers did not attack her, and the queen was able to reach the brood nest and remained there without being harassed.

\section{DISCUSSION}

In both situations, exp. 1, when two sister queens were present, and exp. 2, when one of the queens had been replaced by an unrelated queen, we were unable to detect any kind of preference from the workers toward one of the queens - at least regarding the behavioural categories and frequencies observed. These results have implications both for evolutionary interpretations and with respect to the husbandry field.

\subsection{Evolutionary implications}

If there is a possibility to discriminate queens on the basis of genetic cues, it is not

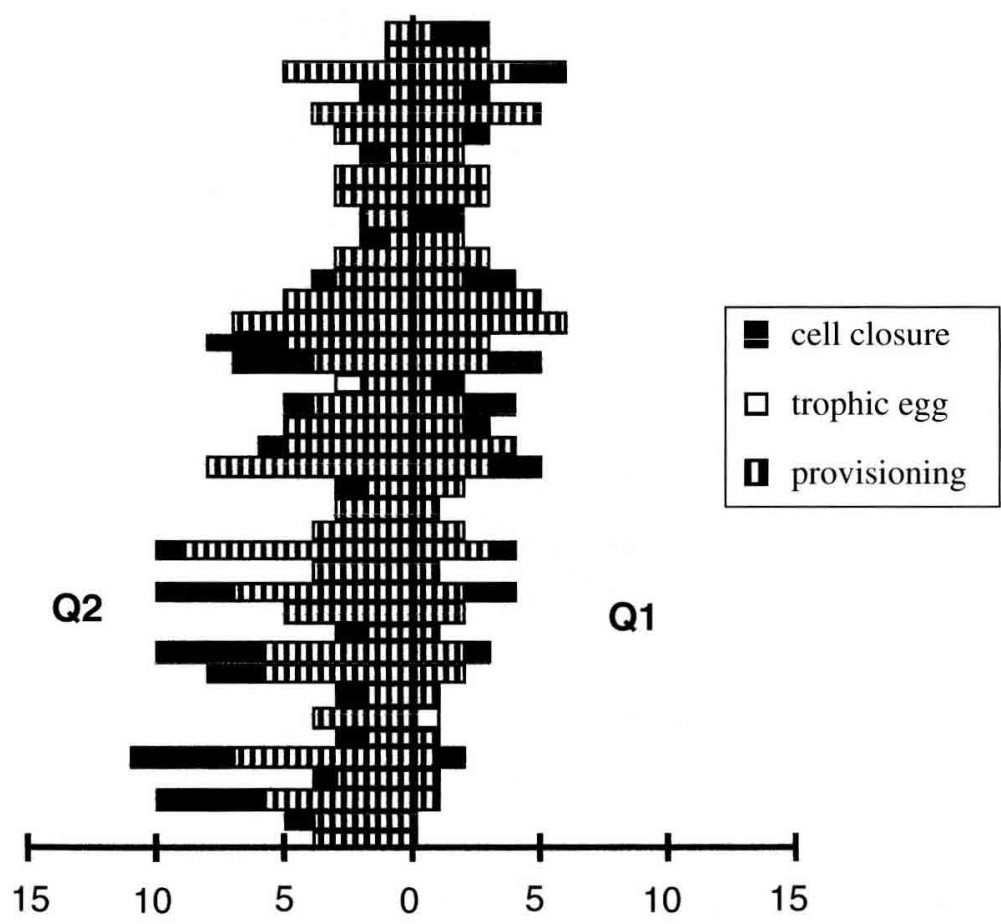

Figure 2. Behaviours performed by each worker (horizontal bars) to each of the sisters qucens (left and right side of the vertical axis: Q2 and Q1, respectively) when only one queen was present. Workers are arranged vertically in a rank derived from the ratio of behaviour performed to Q2 over QI. 


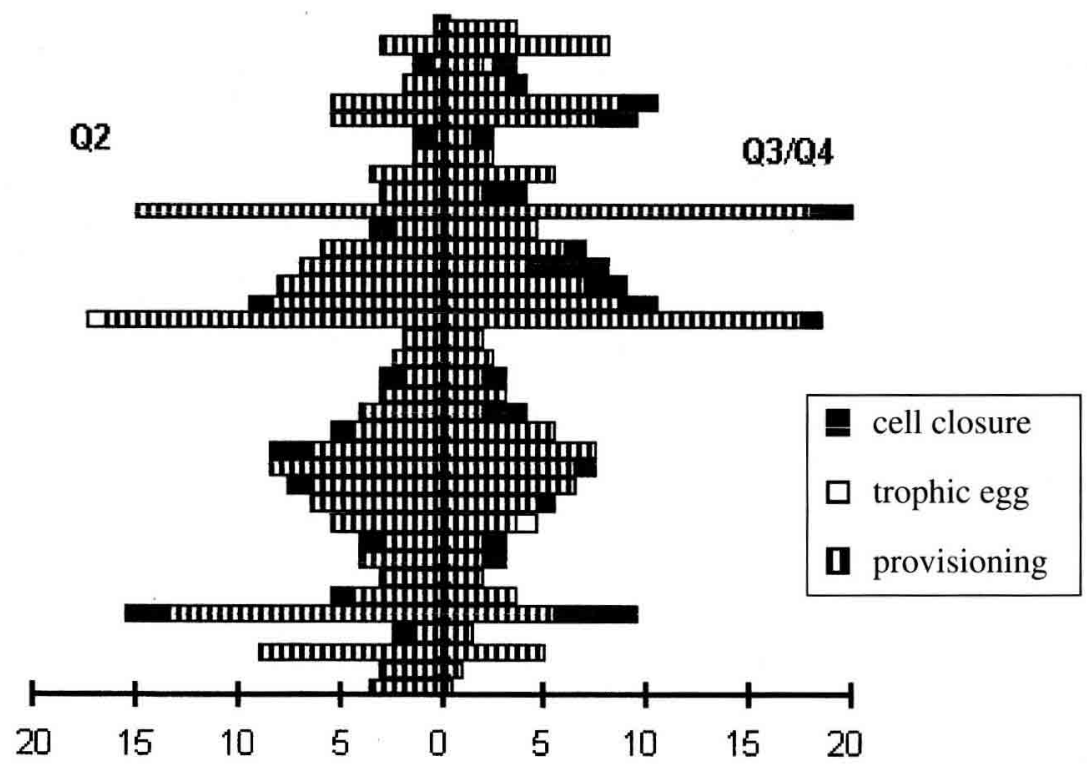

Figure 3. Behaviours performed by each worker (horizontal bar) to the resident queen and to the introduced queens (left and right side of the vertical axis: Q2 and Q3 or Q4, respectively). Workers are arranged vertically in a rank derived from the ratio of behaviour performed to Q2 over Q3 or Q4.

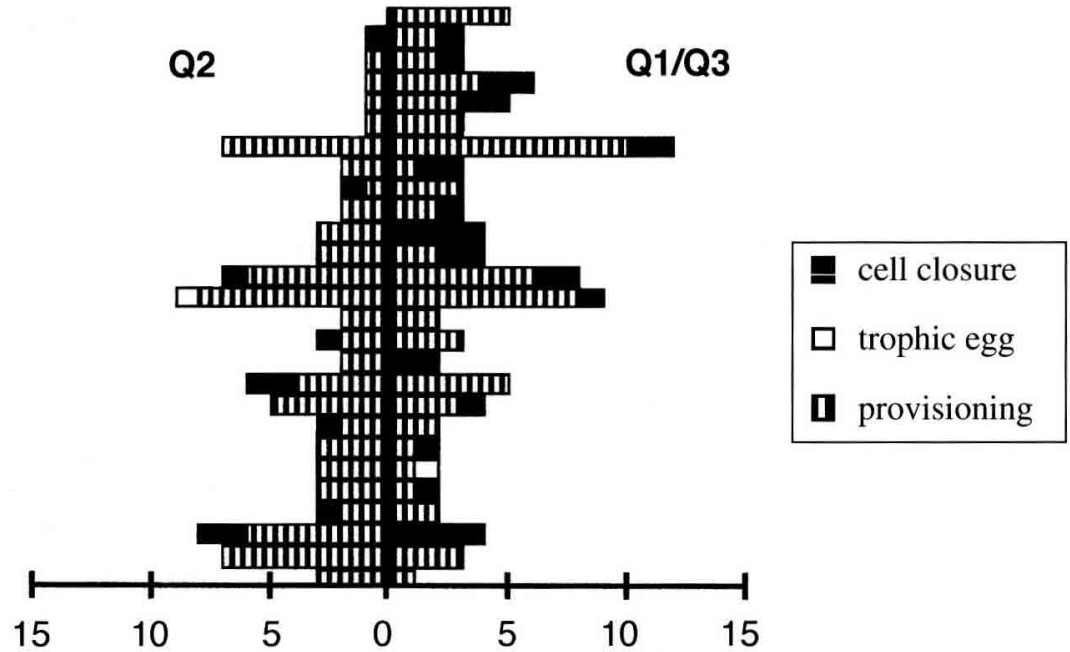

Figure 4. Behaviours performed by each worker (horizontal bars) to the resident queen and to the introduced queens (left and right side of the vertical axis: Q2 and Q3 or Q4, respectively) when only one queen was present. Workers are arranged vertically in a rank derived from the ratio of behaviour performed to Q2 over Q3 or Q4.

being used in an absolute sense by the workers present in the colony. We can then deduce that workers either do not enhance their inclusive fitness through kin discrim- ination during the POP in polygynous colonies, or that they lack the possibilities to do so, in the sense that: "The social behaviour of a species evolves in such a way that in 
each distinct behaviour-evoking situation the individual will seem to value his neighbours' fitness against his own according to the coefficients of relationship appropriate to that situation" [10]. In a stingless bee, $M$. compressipes [23] (and for other bees see references therein), it was also verified that workers do not interfere in the fight between a related resident queen and an introduced unrelated one, accepting the winner.

If we consider queen-worker recognition not as a mechanism to discriminate relatedness among the same colony members, but as a mechanism to avoid the entering of foreign queens in order to parasite the colony, we, in fact, should not expect workers to discriminate among physogastric queens, because in Meliponinae these queens are unable to fly and thus unable to parasite a foreign colony ([22] but see [13]). Entering a foreign colony is only possible for young queens before or after the mating flight. However, this aspect of queen behaviour has not been studied yet.

We also showed (exp. 3) that when a physogastric queen is introduced at the entrance of a foreign colony, there is no aggression by the workers (in contrast with the strong rejection experienced by workers of the same Melipona species when they are introduced into a strange colony $[3,12$, 14]). At this stage it does not seem to be a mechanism by which workers discriminate among their own and foreign queens. Probably the recognition and acceptance of a queen only plays a role when newly fecundated queens are involved. However this acceptance is a long process that already begins before the virgin queen has taken flight $[7,11,21,30]$.

\subsection{Beekeping}

Because the interchange of physogastric queens between colonies is not affected by discriminative behaviours of workers, this provides us with a useful tool for the eco- nomic management of this species. Other unpublished data confirm it. In fact, till now this has been a current method of colony management - e.g. to strengthen weak ones (see also [33]). Our results also agree with other experiments that revealed the easiness of exchanging queens in Meliponinae colonies $[20,23]$ - and even among colonies of different species (reviewed by [23]).

\section{ACKNOWLEDGEMENTS}

We thank Cynthia Schuck-Paim, Euphly Jalles-Filho, Jorge R. Lima, Dick Koedam and the anonymous referees for their helpful comments. CAPES (33021163) and $\mathrm{CNPq}$ (521776/96-1 and 521178/95-9) supported this work.

Résumé - Les ouvrières de Melipona bicolor peuvent-elles faire la distinction entre le degré de parenté de diverses reines physogastriques ? La théorie de la sélection de la parentèle prédit qu'un individu peut parvenir à l'adéquation adaptative (fitness) au moyen de la reproduction indirecte en aidant l'élevage des descendants d'un parent et l'on s'attend à ce que cette aide soit dirigée de préférence vers les individus qui partagent un fort degré de parenté avec l'acteur. $M$. bicolor est la seule espèce fortement eusociale connue qui présente une polygynie facultative de longue durée. Nous avons testé la tendance éventuelle des ouvrières à faire la distinction entre des reines physogastriques qui leur sont plus ou moins apparentées. Une colonie possédant deux reines physogastriques, qui s'étaient accouplées quatre mois plus tôt et étaient probablement sœurs, a été suivie pendant cinq jours et cinq nuits de suite du point de vue des processus d'approvisionnement et de ponte (POPs). Nous avons enregistré les types de comportement suivants d'ouvrières marquées individuellement : aprovisionnement de la cellule avant la ponte, ponte avant et après la ponte de la reine, obturation de la cellule après la ponte de la reine. Afin d'évaluer 
l'éventuelle préférence de ces ouvrières marquées pour l'une ou l'autre reine, nous avons enregistré le nombre total de comportement effectués par chaque ouvrière vis-à-vis de chaque reine. La note 1 a été attribuée à la reine lorsque le comportement n'était effectué que vis-à-vis d'une reine, et la note un demi à chaque reine, lorsque les deux reines étaient présentes au cours du POP. Seules les ouvrières que nous avons vu participer à quatre POPs au moins ont été retenues pour l'analyse (figure I). La possibilité que les ouvrières aient pu être stimulées par la présence d'une reine et n'aient pas été inhibées par la présence de l'autre a été prise en considération. Aussi dans une autre analyse, seuls les POPs au cours desquels une seule reine était présente, ont été retenus et nous avons à nouveau testé l'éventuelle préférence des ouvrières (figure 2). Dans les deux cas, les ouvrières ayant réparti leurs activités au hasard sur les cellules fréquentées par les reines, nous en concluons qu'elles n'ont pas de préférence pour l'une ou l'autre des reines. Par ailleurs, nous avons retiré de la colonie utilisée pour l'expérience 1 l'une des reines et l'avons remplacé par deux reines physogastriques non apparentées, prélevées dans d'autres colonies. Nous avons répété le suivi des comportements et refait la même analyse de données ; là encore nous n'avons trouvé aucune préférence des ouvrières, que la reine leur soit apparentée ou non (figures 3 et 4 ). Dans une troisième expérience nous avons recherché si les gardiennes à l'entrée de la colonie rejetaient les reines physogastriques étrangères. Pour cela huit reines physogastriques ont été retirées de leur colonie et immédiatement placées à l'entrée d'une colonie choisie au hasard et possédant une reine. L'introduction a été considérée comme réussie lorsqu'au moins trois heures plus tard la reine pouvait être observée sur le rayon apparemment en bonne santé. Toutes les reines introduites ont été acceptées. Implications sur le plan de l'évolution : si la possibilité existe de discriminer les reines d'après des informations génétiques, elle n'est pas utilisée par les ouvrières présentes dans la colonie. Nous pouvons en déduire soit que les ouvrières n'améliorent pas leur adéquation adaptative globale par la discrimination de parentèle au cours des POPs dans les colonies polygynes, soit que les possibilités de le faire leur font défaut. Avantages pour l'apiculture : puisque les reines physogastriques peuvent être interchangées entre colonies sans que cela ne perturbe les comportements discriminatifs des ouvrières, nous disposons là d'un outil utile pour gérer cette espèce sur le plan économique. Nos résultats sont en accord avec d'autres expériences qui ont montré la facilité d'échanger les reines entre colonies de Meliponinae - même entre colonies d'espèces différentes. (C) Inra/DIB/ AGIB/Elsevier, Paris

\section{Melipona bicolor / reconnaissance parentèle / polygynie / processus d'approvisionnement et de ponte}

Zusammenfassung - Erkennen Arbeite-
rinnen von Melipona bicolor ihren Ver-
wandtschaftsgrad zu verschiedenen phy-
sogastrischen Königinnen? Nach der 'Kin selection' Theorie kann ein Individuum auch durch nicht-eigene Vermehrung einen Fitneßgewinn erreichen, indem es bei der Aufzucht von Nachkommen eines Verwandten hilft. Hierbei ist zu erwarten, da $\beta$ diese Hilfe vorzugsweise den in hohem Maße mit dem Helfer verwandten Tieren zugute kommt. Melipona bicolor ist die einzige bekannte hoch eusoziale Bienenart, bei der für lange Zeit mehrere Königinnen zusammen in einem Nest vorkommen. Es wurde untersucht, ob eine Tendenz der Arbeiterinnen besteht, auf Grund eines unterschiedlichen Verwandtschaftsgrades zu den physogastrischen (eierlegenden) Königinnen zwischen diesen zu differenzieren. Ein Volk mit zwei physogastrischen Königinnen, die wahrscheinlich Schwestern waren und die sich beide 4 Monate zuvor gepaart hatten, wurde an 5 einander folgenden Tagen und Nächten in Bezug auf Zellvorräte und Eiablage überwacht (POP). Wir notierten fol- 
gende Verhaltenskategorien von individuell markierten Arbeiterinnen: Anlegen der Zellvorräte vor der Eilage, Eilage vor und nach dem Eierlegen durch die Königin und Zellverdeckelung nach der Eilage durch die Königin. Um eine mögliche Bevorzugung dieser markierten Arbeiterinnen für die eine oder andere Königin zu bestimmen, wurde die Gesamtzahl von Verhaltensakten jeder Arbeiterin zu jeder Königin registriert. Hierbei wurde jeweils ein Punkt vergeben, wenn sich eine Arbeiterin nur einer Königin oder wenn sie sich bei gleichzeitiger POP beider Königinnen jeweils zur Hälfte jeder Königin zuwendete. Es wurden nur Arbeiterinnen zur Auswertung herangezogen, die bei 4 oder mehr POPs aktiv beteiligt waren $(A b b, 1)$. Zusätzlich wurden die Möglichkeit in Betracht gezogen, da $\beta$ eine Arbeiterin durch die Anwesenheit der einen Königin stimuliert wurde, aber nicht durch die Anwesenheit der anderen Königin gehemmt wurde. Deshalb wurden in einer weiteren Analyse nur solche POPs berücksichtigt, in der nur eine Königin beteiligt war. Auch hier wurde getestet, ob die Arbeiterinnen eine Bevorzugung zeigten ( $A b b .2)$. Aus den Beobachtungen, da $\beta$ in beiden Fällen die Arbeiterinnen in einer zufälligen Weise bei Zellen aktiv waren, die von jeder der Königinnen besucht wurde, wurde geschlossen, da $\beta$ sie keine der beiden Königinnen bevorzugten. Weiterhin wurde eine Königin aus dem im ersten Versuch benutzten Volk entfernt und durch eine nicht verwandte physogastrische Königin aus einem anderen Volk ersetzt. Wir wiederholten die Registrierung des Verhaltens und dieselbe Datenanalyse, und wieder fanden wir keine Bevorzugung von den Arbeiterinnen für verwandte oder nicht verwandte Königinnen ( $A b b .3$ und 4). In einem 3. Versuch wurde untersucht, ob eine physogastrische fremde Königin von Wächterbienen am Stockeingang abgewiesen würde. Acht physogastrische Königinnen wurden aus ihren Völkern entfernt und sofort vor den Eingang einer zufällig ausgewählten weiselrichtigen Kolonie gesetzt. Als erfolgreiche Annahme wurde gewertet, wenn eine Königin auf der Wabe mindestens 3 Stunden nach dem Zusetzen auf einer Wabe beobachtet wurde. Alle Königinnen wurden angenommen. Evolutionäre Schlu $\beta$ folgerungen: Wenn es die Möglichkeit einer Unterscheidung der Königinnen auf Grund von genetischen Merkmalen gibt, so würde dies jedenfalls nicht in einer absoluten Weise von den Arbeiterinnen eines Volkes genutzt. Wir können danach folgern, da $\beta$ Arbeiterinnen entweder ihre inklusive Fitne $\beta$ nicht durch 'Kin Diskriminierung' während der POP in polygynen Völkern steigern, oder da $\beta$ ihnen die Möglichkeit zu einer Diskriminierung fehlt. Vorteile bei der Bienenhaltung: Da der Austausch von physogastrischen Königinnen zwischen den Völkern nicht durch das Verhalten von Arbeiterinnen beeinflußt wird, wird uns eine nützliche Methode zur ökonomischen Haltung dieser Art ermöglicht. Unsere Ergebnisse stimmen mit anderen Versuchen überein, die ebenfalls den mühelosen Austausch von Königinnen in Völkern der Meliponen sogar zwischen Völkem von verschiedenen Arten - aufzeigten. (C) Inra/DIB/AGIB/Elsevier, Paris

\section{Kin recognition / Polygynie / Prozesse des} Zellvorrats und Eilage / Melipona bicolor

\section{REFERENCES}

[1] Alexander R.D., Social learning and kin recognition, Ethol. Sociobiol. 12 (1991) 387-399.

[2] Bego L.R., Behavioral interactions among queens of the polygynic stingless bee Melipona bicolor bicolor Lepeletier (Hymenoptera, Apidae), Braz. J. Med. Biol. Res. 22 (1989) 587-596.

[3] Breed M.D., Page R.E., Intra- and interspecific nestmate recognition in Melipona workers (Hymenoptera: Apidae), J. Insect. Behav. 4 (1991) 463-469.

[4] Breed M.D., Welch C.K., Cruz R., Kin discrimination within honey-bee (Apis mellifera) colonies - an analysis of the evidence, Behav. Processes 33 (1994) 25-39.

[5] Carlin N.F., Discrimination between and within colonies of social insects: two null hypotheses, Neth. J. Zool. 39 (1989) 86-100.

[6] Carlin N.F., Frumhoff P.C., Nepotism in the honey-bee, Nature 346 (1990) 706-707. 
[7] Engels W., Imperatriz-Fonseca V.L., Caste development, reproductive strategies, and control of fertility in honey bees and stingless bees, in: Engels W., (Ed.), Social Insects, Spinger Heidelberg, New York, 1990, pp. 167-243.

[8] Grafen A., Do animals really recognize kin? Anim. Behav. 39 (1990) 42-54.

[9] Grafen A., Kin vision - reply, Anim. Behav. 41 (199l) 1095-1096.

[10] Hamilton W.D., The genetical theory of social behaviour I, II, J. Theor. Biol. 7 (1964) 1-52.

[11] Imperatriz-Fonseca V.L., Zucchi R., Virgin queens in stingless bee (Apidae, Meliponinae) colonies: a review, Apidologie 26 (1995) 231-244.

[12] Inoue T., Roubik D.W., Kin recognition of stingless bee, Melipona fasciata, in: Veeresh G.K. Mallik B., Viraktmath C.A. (Eds.), Social Insects and the Environment, Oxford \& IBH, New Delhi, 1990, pp. 517-518

[13] Inoue T., Sakagami S.F., Salmah S., Nukal N. Discovery of successful absconding in the stingless bee Trigona (Tetragonula) laeviceps, J. Apic. Res. 23 (1984) 136-142.

[14] Inoue T., Roubik D.W., Suka T., Nestmate recognition in the stingless bee Melipona panamica (Apidae: Meliponini), Insectes Soc. (in press).

[15] Keller L., Indiscriminate altruism: unduly nice parents and siblings, Trend. Ecol. Evol. 12 (1997) 99-103.

[16] Kerr W.E., Algumas comparações entre a abelha européia (Apis mellifera $\mathbf{L}$.) e as abelhas nativas brasileiras (Meliponini), O Solo, Out (1949) 39-47.

[17] Kerr W.E., Some aspects of the evolution of social bees (Apidae), Evol. Biol. 3 (1969) 119-175.

[18] Kerr W.E., Krause W., Contribuição para o conhecimento da bionomia dos Meliponini. Fecundação da rainha em Melipona quadrifasciata Lep (Hymenoptera - Apoidea), Dusenia 1 (1950) 275-282.

[19] Kerr W.E., Zucchi R., Nakadaira J.T., Butolo J.E., Reproduction in the social bee (Hymenoptera: Apidae), J. N. Y. Entomol. Soc. 70 (1962) 265-276

[20] Kleinert-Giovannini A., Mecanismos de controle reprodutivo em Melipona marginata Lepeletier (Apidae, Meliponinae), $\mathrm{Ph} . \mathrm{D}$. dissertation, Ecology Department, Institute of Biosciences, University of São Paulo, São Paulo, 1989.

[21] Koedam D., Aguilar-Monge I., Sommeijer M., Social Interactions of gynes and their longevity in queenright colonies of Melipona favosa (Apidae: Meliponinae), Neth. J. Zool. 45 (1995) 480-494.

[22] Michener C.D., The Social Behavior of Bees, Belknap Press of Harvard University Press, Cambridge, Massachusetts, 1974.
[23] Monteiro C.A., Kerr W.E., Experimental exchange of queens between colonies of Melipona compressipes (Apidae, Meliponini), Rev. Bras. Biol. 50 (1990) 975-981.

[24] Oldroyd B.P., Rinderer T.E., Buco S.M., Nepotism in the honey-bee, Nature 346 (1990) 707-708.

[25] Pamilo P., Gertsch P., Thorén P., Seppä P., Molecular population genetics of social insects, Annu. Rev. Ecol. Syst. 28 (1997) 1-25

[26] Ramalho M., Diversidade de abelhas (Apoidea, Hymenoptera) de um remanescente de floresta atlântica em São Paulo, Ph.D. dissertation, Ecology Department, Institute of Biosciences, University of São Paulo, São Paulo, 1995.

[27] Sakagami S.F., Techniques for the observation of behaviour and social organization of stingless bees by using a special hive, Papéis Avulsos do Depto de Zool, Secret. de Agric. de São Paulo 19 (1966) 151-162

[28] Sakagami S.F., Stingless bees, in: Herman, H.R. (Ed.), Social Insects, Vol III, Academic Press, New York, 1982, pp. 361-423.

[29] Sakagami S.F., Zucchi R., Oviposition process in a stingless bee, Trigona (Scaptotrigona) postica Latreille (Hymenoptera), Studia Entomol. 6 (1963) 497-510

[30] Silva D.L.N. da, Zucchi R., Kerr W.E., Biological and behavioural aspects of the reproduction in some species of Melipona (Hymenoptera, Apidae, Meliponinae), Anim. Behav. 20 (1972) 123-132.

[31] Stuart R.J., Kin recognition as a functional concept, Anim. Behav. 4 I (1991) 1093-1094.

132] Velthuis H.H.W., Pollen digestion and the evolution of sociality in bees, Bee Word 73 (1993) 77-89.

[33] Vencovsky R., Kerr W.E., Melhoramento genético em abelhas. 2. Teoria e avaliação de alguns métodos de seleção, Rev. Brasil. Genet. 5 (1982) 493-502.

[34] Visscher P.K. Colony integration and reproductive conflict in honey bees, Apidologie 29 (1998) 23-45

[35] Waldman B., Frumhoff P.C., Sherman P.W., Problems of kin recognition, Trends. Ecol. Evol. 3 (1988) 8-13.

[36] Wilms W., Imperatriz-Fonseca V.L., Engels W., Resource partitioning between highly eusocial bees and possible impact of the introduced africanized honey bee on native stingless bee in the Brazilian Atlantic rainforest, Stud. Neotrop. Fauna Environ. 31 (1996) 137-151.

[37] Zar J.H., Biostatistical Analysis, 3rd ed., Prentice-Hall, Upper Saddle River, 1996.

[38] Zucchi R., Ritualised dominance, evolution of queen-worker interactions and related aspects in stingless bees (Hymenoptera: Apidae), in: Inoue T., Yamane S. (Eds.), Evolution of Insects Societies, Hakuhin-sha, Tokyo, 1993, pp. 207-249 